\title{
The Collective European Memory of 1968: The Case of Northern Ireland
}

\section{Chris Reynolds}

\section{(2) OpenEdition \\ 1 Journals}

\section{Electronic version}

URL: http://journals.openedition.org/etudesirlandaises/2146

DOI: 10.4000/etudesirlandaises. 2146

ISSN: 2259-8863

\section{Publisher}

Presses universitaires de Rennes

\section{Printed version}

Date of publication: 30 June 2011

Number of pages: $73-90$

ISBN: 978-2-7535-1348-8

ISSN: 0183-973X

\section{Electronic reference}

Chris Reynolds, «The Collective European Memory of 1968: The Case of Northern Ireland ", Études irlandaises [Online], 36-1 | 2011, Online since 30 June 2013, connection on 19 April 2019. URL : http:// journals.openedition.org/etudesirlandaises/2146; DOI : 10.4000/etudesirlandaises.2146

This text was automatically generated on 19 April 2019.

(c) Presses universitaires de Rennes 


\title{
The Collective European Memory of 1968: The Case of Northern Ireland
}

\author{
Chris Reynolds
}

1 In 1968, all across Western Europe, governments and regimes were rocked by a wave of protest movements that seemingly shared more than a coincidence of timing ${ }^{1} .2008$, more so than any commemorative period thus far, saw a real drive to go beyond strictly national perspectives with much attention on the international dimension of revolts at this time ${ }^{2}$. The aim, it seems, is to address the question as to the existence of a common international/European revolt. An ever-growing list of countries and regions from all around the world that in some way fit the model of what happened in 1968 has emerged ${ }^{3}$. Despite the great contextual differences that set so many of these countries apart, a collective movement is increasingly perceived and described as characterising the revolts, thus lending weight to the ever-popular representation of 1968 as a year of international upheaval ${ }^{4}$.

2 The French revolt has emerged as that which is seen to typify the tumultuous events of that year ${ }^{5}$, with, as Gildea describes, the Latin Quarter of Paris as its "epicentre ${ }^{6 "}$. There are several reasons to explain why this is the case. Amongst them is the fact that, unlike any other 1968 revolt, the French "May Days" were transformed from what was essentially a student-based movement into an all-out social crisis that threatened the hitherto extremely stable Gaullist regime. As such, it can be held up as an example of the explosive potential of what has been described a revolutionary period. However - and perhaps more significantly in this age of images, symbolism and aesthetics driven by technological advances that have led to a certain commemorative mediatisation of history and memory ${ }^{7}$ - the characteristics of the conventional representations of the French events have helped mould an iconic image of what happened and one that is both romantic and attractive ${ }^{8}$. So starkly do these images contrast with current-day concerns that their appeal is unsurprising 9 . Just as events in Paris have monopolised the national memory of the 1968 in France - with obvious drawbacks ${ }^{10}$ - the French revolt can be 
described as having done something similar in terms of the collective European memory of 1968.

One country that has not commonly been seen to sit comfortably as part of this international revolt is Northern Ireland (NI). Two possible conclusions could be drawn from the virtual absence of Northern Ireland from the long list of countries described as being affected by this international wave of revolt. Firstly, it could be assumed that there was no significant movement in 1968 in Northern Ireland. This is quite simply not the case. 1968 was to prove a pivotal year which, for many, marks the beginning of the "Troubles". Alternatively, it could be surmised that the movement in Northern Ireland does not fit the "68" mould. This article seeks to challenge this idea. Through a comparison with the French events of 1968, it will be argued that Northern Ireland should be included in the list of countries that make up this international upheaval. Reasons explaining why this has not been the case to date will be provided before a conclusion on how and why this is beginning to change.

\section{From repression to election}

\section{France, May-June 1968}

4 On 3 May 1968, following a period of disruption at the Nanterre campus in the Parisian suburbs, a band of militant students decided to take their protest to the heart of the French university system, the Sorbonne ${ }^{11}$. Reacting to a rumour of an imminent attack from the fascist Occident movement, they tore up tables and chairs in a bid to protect themselves. The subsequent decision to have them cleared from the courtyard of the Sorbonne was to become the starting point of one of the most important events in recent French history. The perceived mishandling of this situation by the forces of order sparked a riot in the student quarter and was the first in a week-long series of clashes ${ }^{12}$, culminating in the infamous Night of the Barricades on 10 May $^{13}$. The heavy-handed tactics were so badly perceived by the public that a general strike was called for Monday 13 May, marking a transition of the student protest to one of the society as a whole ${ }^{14}$. By 20 May France was completely paralysed ${ }^{15}$. Previously reluctant, unwilling or completely overcome by the unfolding events, President de Gaulle and his Prime Minister Georges Pompidou made clear attempts to resolve the situation, and both failed ${ }^{16}$, leading to the most dangerous phase of the crisis. However, despite the brief threat of the revolt finding a political outlet, de Gaulle was eventually able to redress the situation and seemingly shake the population from its momentary folly ${ }^{17}$. On May 30 , once back from his mysterious trip to Baden-Baden, he decided to address the population for a second time ${ }^{18}$ and through allusions to the threat of totalitarianism and chaos turned the situation on its head. His dissolution of the Assembly and the calling of legislative elections marked the beginning of the end of the revolt ${ }^{19}$. The extraordinary turnaround was confirmed by the landslide Gaullist victory in the elections of 23 and 30 June $1968^{20}$.

Despite their ephemeral nature, the events of Mai 68 have become a reference point in French history and are considered as a watershed in the development of French society ${ }^{21}$. The French events cannot be considered in isolation to what was happening elsewhere at the time. In fact, they drew inspiration from, rode the wave of and contributed to an international revolt. The vast array of contextual differences from country to country problematises an explanation of what drove the common expression of frustration. 
However, one pertinent line is that which refers to the "decline of deference ${ }^{22}$." Stefan Collini describes the "sixties" as the culmination of a process of unprecedented socioeconomic and cultural change that brought about democratisation coupled with significant prosperity. Such seismic shifts led to the rules and traditions that hitherto governed society being exposed to question and criticism. The driving force behind this tension that exploded with such enthusiasm for change was the youth of the time who "realized that recent social changes meant that they no longer had to wait their turn: they could take over the place immediately ${ }^{23}$ ". Whilst this interpretation refers to 1960 s Britain, it could equally be applied to most of those Western European nations that experienced revolt in 1968 and points to an important transnational common denominator. This is particularly important when comparing France with Northern Ireland.

\section{Northern Ireland, October 1968-February 1969}

6 On 5 October 1968 the second march for Civil Rights in Northern Ireland took place in Duke Street, Derry. Attended by upwards of 2,000 people including a delegation from Queen's University Belfast (QUB), the march ended in terrible violence as the police - the Royal Ulster Constabulary (RUC) - waded in with a heavy-hand and used brutal repression to enforce the previously imposed ban on the demonstration. The broadcasting of footage of the clashes on Radio Telefís Éireann (RTE, National television network of the Irish Republic) made sure of nationwide and international revulsion ${ }^{24}$. This march and the mishandling of it by the police had a profound impact on those QUB students present and would lay the foundations for the birth and emergence of a significant movement in the ensuing period of protes $^{25}$. On 9 October 1968, a demonstration was organised by the students of QUB in protest against the police brutality in Derry. A meeting was later held at the University during which the People's Democracy (PD) was born. Led by a "faceless committee" which included a university lecturer ${ }^{26}$, graduates and undergraduates, this essentially student movement was officially launched on 11 October 1968. As well as quite specific demands related closely to those of the Northern Ireland Civil Rights Association (NICRA) ${ }^{27}$, the PD was concerned with raising awareness and lobbying the government on issues of social injustice and discrimination. In the initial phase this was achieved via provocative, non-violent acts intended to embarrass and force government representatives to consider the issues at hand ${ }^{28}$. As the movement gathered momentum it was becoming increasingly difficult to maintain the non-violent approach and therefore continue to benefit from the public support they had enjoyed thus far ${ }^{29}$. Tensions were not only obvious from the exterior. It was becoming increasingly clear that there were difficulties within the ranks of the PD itself ${ }^{30}$. It was the episode of the "Long March" that while, on the one hand would ensure a critical place for the PD in the civil rights movement, on the other would expose the rifts that would eventually be the movement's greatest weakness.

7 The idea of a "Long March" from Belfast to Derry had been discussed and provisionally planned for 14 December before being shelved. Its postponement was a direct consequence of a number of proposed reforms and the Northern Ireland Prime Minister Captain Terence O'Neill's famous "crossroads" speech ${ }^{31}$. Many saw this as a genuine attempt at making progress and an "unofficial referendum ${ }^{32}$ "was organised by the Belfast Telegraph. Over 75.000 people filled in specially commissioned coupons from the 
newspaper declaring support for O'Neill. The moderate majority was able to force a truce during which no marches or direct action would take place ${ }^{33}$. However, for others this was proof of what could be achieved via direct action ${ }^{34}$. Such elements within the PD were able to force through a reversal of the decision to postpone the long march which was rescheduled to leave Belfast on 1 January ${ }^{35}$. The march set off with a very small number of participants and little public support. However, by the time it reached the Burntollet bridge on the outskirts of Derry, where it was met by a well organised and allegedly police-supported ambush ${ }^{36}$, participation and support had swollen, elevating those involved to the status of heroes and martyrs for the civil rights cause in Northern Ireland ${ }^{37}$. Despite this success, the subsequent violent backlash saw the PD accused of radicalising the civil rights movement and undermining the "steady, steady approach" of moderate elements thus far ${ }^{38}$. It was in the light of such tension and criticism that the PD decided to scale down its action and turn its attention to the next stage; the General Elections that Terence O'Neill was forced to call for 24 February $1969^{39}$. The PD decision to participate in this election was to prove a critical one. By entering into electoral politics - despite relative success in terms of votes -, the PD had moved to another stage in its development. Its originality was diluted and a process began that would end with the PD being subsumed into the more general revolt that would become the "Troubles". As Prince argues: "The old conflict over national and communal identities had been renewed. Northern Ireland's 68 had ended ${ }^{40}$ ".

8 As well as originating as university-based movements, both periods of protest in Northern Ireland and in France were triggered in reaction against police brutality. Both were also brought to a close - in admittedly different ways - by general elections. The following section will demonstrate that these are not the only parallels that can be drawn between Belfast and Paris in 1968.

\section{Northern Ireland and France: comparable/common revolts?}

9 It is clear that movements from around the world looked to each other for support and inspiration in terms of action, ideas or organisation ${ }^{41}$. The French movement certainly drew influence from similar movements in the USA, in West Germany and in Japan ${ }^{42}$. There were international issues (particularly the Vietnam War) that cultivated this notion of worldwide protest and fostered the idea of a shared, international revolt against a common enemy. In the years preceding 1968 , politically active students at QUB such as Eamonn McCann, Cyril Toman and Michael Farrell had not only followed the development of this international protest movement but had also participated in meetings, conferences and demonstrations that had taken place. As Prince describes: "Northern Ireland was not under quarantine while the revolutionary contagion raged throughout the West ${ }^{43}$." When the students of QUB started the new academic year of 1968-69 they cannot have been oblivious to what had been happening around the world in the preceding few months. When one considers the way in which the French events in particular were raked over in their immediate aftermath, it is no surprise that they "were fresh in the memory ${ }^{44}$." Furthermore, the new university year started only three days following the decisive 5 October March in Derry thus offering the opportunity to the young people of Northern Ireland to book their place in this international revolt ${ }^{45}$. 
Similar root causes help explain why these young people may have felt they too should be part of this global wave of protest.

As had been the case in France in the years leading up to May 68, there had been, in Northern Ireland, a period described by Gibbon as "deceptively quiet" for "in fact, beneath the surface, the conditions for a major crisis had been accumulating for some time ${ }^{46}$." De Gaulle's success in bringing an end to the Algerian crisis meant that in France the period from 1962-68 was one that saw the 5th Republic lay solid foundations and provide a long-awaited period of stability. 1962 was not without significance in Northern Ireland, for it was this year that marked the end of the IRA's six-year cross border campaign (operation Harvest) ${ }^{47}$. In both cases a period of violence and uncertainty gave way to one of relative calm. Generational and socio-economic changes at play during this time help explain why the revolts came along and why the university served as their starting points.

11 Northern Ireland, like France, had been enjoying relative political stability as well as the benefits brought about by the economic boom and the rise of the consumer society ${ }^{48}$. Such changes spurred young people to dare ask questions of and challenge the state of affairs. As Arthur explained to me, this example of the "decline of deference" meant that his "generation was not going to take what they [the older generation] had to take ${ }^{49}$ ". In France opposition mounted vis-a-vis the elder statesman pacifying the population with consumer products as he pressed on with his notions of grandeur ${ }^{50}$. In Northern Ireland a new generation of young people (particularly from the catholic population) was becoming increasingly unwilling to accept the status quo of religious discrimination. In both countries, it was the spoils of socio-economic progress that fuelled the sense of revolt and provided the launch pad for the respective upheavals.

12 In France, the baby boom together with economic progress saw the university system opened up to welcome sectors of the society that had hitherto been denied such a privilege. These changes and the failure to cater for them are correctly cited as fundamental in explaining why this institution served as the spark for the French events ${ }^{51}$ . The conditions of the higher education system provided the grounds from which its swelling masses could contemplate and critique society in general. Faculties such as Nanterre became perfect breeding grounds for discontent ${ }^{52}$. Similar changes can be delineated in Belfast. As Northern Ireland experienced an (albeit brief) spell of political and economic stability, a new element began to affirm itself in the echelons of the system of higher education ${ }^{53}$. A body of well-educated Catholics was now able to observe the frailties of the NI State and felt as though they were in a position to react. Gibbon explains how QUB provided an exceptional space from a NI perspective. The unsegregated nature of the institution meant that students - whilst increasingly aware of the shortcomings of the status quo - were freed from family/community hatred and bigotry and thus able to consider their plight from a broader perspective ${ }^{54}$. Consequently "[T]he world-wide wave of student revolt could not but have a violent impact on the one student group in the British Isles daily confronted with the repressive paraphernalia of a police state $^{55}$. With such evidently clear similarities in mind, it is no surprise then that closer examination of the action, language and general atmosphere of this period in Northern Ireland highlights even further correlation with the French events.

13 At the inaugural meeting of the PD on 9 October an undercurrent of frustration and desire for change was channelled through a system that, as Michael Farrell later admitted, was "considerably influenced by the Sorbonne assembly ${ }^{56 "}$. The room was open 
to anyone who wished to intervene and there was no (official) hierarchy. As Levy details, "Par son fonctionnement, comme par son esprit, la P.D. d'alors ressemblait fort au Mouvement du 22 Mars $^{57 "}$. A faceless committee made up of students and staff of QUB was elected. Agendas were discussed and decided on by the meeting itself. Overall this "ultrademocratic structure" was to be a common feature of how the PD would make decisions and conduct itself $^{58}$. Initially, this was one of the movement's greatest strengths, however, it was to be at the root of its downfall ${ }^{59}$. As had been the case in France ${ }^{60}$, the novelty of such action was the butt of much criticism from established bodies that deemed such organisational structures as unmanageable and inefficient ${ }^{61}$. These organisational similarities can hardly be viewed as merely coincidental. When one considers the timing along with the common traits it is clear that a certain degree of influence was sourced from abroad in similar movements ${ }^{62}$. As Paul Arthur explained to me : "A number of us were self-consciously following the French... the notion of meetings that went on and on, we believed that was part of what had happened in Paris ${ }^{63}$." In order to understand why these tactics were imported with such ease one has to recognise the role of the media.

Radio, newspaper and television coverage was critical in creating the grounds whereby, Europe-wide, activists could situate themselves and their struggles in an international perspective $e^{64}$. The specific focus of international coverage on the spectacular elements of each revolt negated any real understanding of specific local contexts and instead encouraged militants to search for more general common denominators. The existence of any differences were glossed over as broader issues (anti-authoritarianism, the desire for wholesale change, anti-imperialism, anti-capitalism, anti-war movements, etc) brought militants together, adding a degree of credibility to the respective upheavals through the belief that they each formed part of a broader, international wave of protest. Students in Belfast could not help but be inspired by the events of the previous spring in Paris - a fact evident when one considers some of the common action repertoires ${ }^{65}$.

Just as "la rue" was very important in France ${ }^{66}$, protest marches, punctuated with slogans and revolutionary songs, helped the rise to prominence of the PD in Northern Ireland. By insisting on the right to march, the inevitability of clashes with the police revealed the intention on behalf of certain student elements to provoke a violent reaction from the police that would in turn heighten the profile of the movement amongst the population and guarantee a certain degree of public sympathy and support ${ }^{67}$. The Nanterre example of "Provocation-Répression-Solidarité" was not lost on the PD. This provocation at times fed into an element of playfulness and youthful disdain for authority or "political theatre ${ }^{68 \text { " }}$ that conjures up images of the utopian, surrealist label so commonly attached to the French events ${ }^{69}$. The importation and adaptation of such tactics can be identified notably in the shared use of the deliberately provocative CRS=SS/ RUC=SS slogans. However, one of the most visibly striking similarities concerns the use of posters. The silk-screen prints produced in l'Ecole des Beaux-Arts in Paris in 1968 were immediately the source of much interest and have continued to be so, making them instantly recognisable and explaining why they form such an integral part of 1968 folklore $^{70}$. Whether it is in relation to the technique used to produce the posters, their form or their content, when one considers several examples of PD posters the degree of influence is clear ${ }^{71}$. Those involved in the production of the posters have acknowledged the influence of Paris. For example, Joe Mulheron - member of the PD - described how the "images from France struck [him]" and how "the PD used them, ripped them off ${ }^{72}$ ". The combination of such novel tactics may 
have gained some sympathy due to the freshness they brought to the political scene at the time. However, together with the notion of ultra democracy they helped isolate the PD from bodies such as the broader NICRA and significantly the Communist Party of Northern Ireland (CPNI).

As had been the case in France ${ }^{73}$, there was a difficult relationship between what the CPNI saw as irresponsible and potentially dangerous leftist elements and what the PD saw as an aging, conservative and incapable political force. Despite this problematic relationship with the CPNI, students (and particularly the more politically aware amongst them) were conscious that as long as their movement remained within the confines of the university milieu its general impact would always be limited ${ }^{74}$. Paul Arthur described one particular tactic that reveals the awareness of certain elements of the need to get the working class on board. He explained how students descended on a local social security office where hundreds of unemployed Catholics came to sign on for benefits in a bid to persuade them that their struggle was not simply a "student movement" but one that had to embrace everyone $\mathrm{e}^{75}$. Such anecdotes cannot help but remind one of the (failed) attempts by Parisian students to strike up relations with Renault workers at Billancourt ${ }^{76}$.

Another area beyond the university milieu that reveals parallels concerns the respective states' reactions to the mounting tension and, in particular, decisions taken at the top of the governments. Both de Gaulle and O'Neill appeared on television calling on the "silent majority" in a bid to stem the tide of violence. The French president addressed the population on two occasions. The first (24 May) was a complete failure whilst the second (30 May) is widely regarded as the marking the beginning of the end of the French events ${ }^{77}$. Whilst the outcomes may have differed, in both instances the objectives were the same. The General wanted to offer the population a clear choice - "moi ou le chaos ${ }^{78}$ ". O'Neill's "crossroads" speech was strikingly similar. He too presented the population with an ultimatum and like de Gaulle hoped to dispel tensions by presenting himself and the idea of order and stability as the logical alternative to the growing instability that had flared up in the preceding weeks ${ }^{79}$. Such tactics were - in the short-term - successful for de Gaulle and O'Neill but ultimately were hollow victories as in both their cases 1968 proved to mark the beginning of their respective spells at the top. Other parallels can be delineated within the corridors of power in Belfast and Paris.

Divisions at the top of government were important in deepening the crises in both countries. In France, the fact that the President and the Prime Minister both failed in their respective (and very different) attempts at putting an end to the crisis helped exacerbate the sentiment that the State was on the verge of collapse ${ }^{80}$. Such precariousness was heightened by - and can help explain - the degree of anxiety experienced when the General momentarily disappeared on 30 May. De Gaulle's trip to Baden-Baden not only sparked a brief period of panic, it also drove Georges Pompidou to offer his resignation. Whilst his offer was rejected, this episode nevertheless underlined the extent of the differences between the President and his Prime Minister ${ }^{81}$. Similar high-level tensions were discernable in NI. In the weeks building up to his 'Crossroads' speech, O'Neill had been coming under increasing internal pressure - and none less so than from William Craig82. The Home Affairs minister had been openly and increasingly critical of the PM's line in a clear attempt to wrestle control of the Unionist party. Whilst O'Neill was able to dispense with Craig in the light of the success of his televised address, the evident split revealed the extent of the pressure and in many respects mirrored what had happened in France. 

conducted by an irresponsible minority in order to undermine the movement and divert potential sympathisers. This was a common feature of the tactic employed by the authorities in France ${ }^{83}$ who at one stage claimed that the upheaval had been hijacked by what it described as la pègre ${ }^{84}$. In NI and in particular following the Long March, O'Neill was keen to play down any resonance this moment had within the community at large, "We've always had extreme Protestants and extreme Catholics - the anarchists and the Trotskyites are something new. About 95 per cent or even 99 per cent of the students don't want violence, but a small minority doesn't care ${ }^{85 "}$.

On many levels, accounts of the time reveal a range of similarities in the language, atmosphere and conduct of the movement. One particularly pertinent example of this is the fact that in both Paris and Belfast the student revolt was not limited to a minor nucleus of hardcore militant students, even if it was being driven on by them. In fact, in both cases, the conditions were such that students who had until then remained on the fringes of or completely absent from political activity suddenly found a voice ${ }^{86}$. Police brutality incensed the general student population to such a degree that it compelled the average student to swell the ranks and as such provided an added dimension. Such commonalities (not to mention the internationalist perspective of people such as Paul Arthur who was both heavily involved in the PD as well as providing one of the most detailed accounts of the period) explain why when reading literature on how 1968 was experienced in QUB one could be forgiven for thinking that it was an account of events in Paris $^{87}$.

21 One of reasons why the events in France have been such a focus of discussion over the last forty years is partly due to their "insaisissable" nature ${ }^{88}$. Since the immediate aftermath, commentators, participants and analysts have attempted to make sense of what occurred by searching for a single interpretation of these exceptional events leading to what Philippe Artières describes as "un gigantesque événement de papier"89". The "interpretation" debate has been the focus of much attention and numerous studies, but has yet to come to a conclusion upon which consensus has been reached ${ }^{90}$. However, one of those that comes closest to helping make sense of May-June 1968 is that which sees it as a "revelatory crisis"; the student revolt sparked and exacerbated by police brutality and state incompetence provided the platform for the society at large to express its disenchantment with a social, political and economic situation that had been hidden beneath a veneer of stability and contentment. As explained above, the "decline in deference" provided the impetus for young people in particular to dare expose such frailties in the quest for change. A similar interpretation could be applied to the contribution of the PD in Northern Ireland. Through its novel approach, its unorthodox organisation and daring actions, the PD was able to highlight the problems of a community and boost a struggle that had stagnated for some time. This is a view shared by some major protagonists of the movement. For example, Eamonn McCann explained, "there was an underlying crisis in Northern Ireland which was hidden and to a certain extent was brought to the surface by the events of 1968. ... When the RUC attacked the civil rights march on October 5 in Duke Street all of those things suddenly erupted on to the surface ${ }^{91}$ ". Also, as Paul Arthur indicated, "A number of things were happening beforehand [...] and what the PD did was brought it all out into the open ${ }^{92 "}$. 


\section{A justifiable absence?} is left wondering why - if 1968 in Belfast was so similar to, and in many respects fits, the mould of the Parisian example - the former is so often absent from representations of this global revolt. The obvious answer would be to highlight the great contextual differences that existed between Northern Ireland and the rest of the world at the time. The very specific circumstances of late 1960s Northern Ireland are such that it is understandable why commentators have refrained from including Belfast in the same breath as Rome, Paris, and Berlin ${ }^{93}$. And yet one cannot get away from the fact that in spite of such contextual differences, a "68-style" movement took place. Three elements in particular require consideration in order to understand why Belfast/NI 1968 is absent from the European collective memory of this year.

The first relates to the insular nature of Northern Ireland and its population. Due to geographical factors, and compounded by the idea that the NI problem was a case apart, what happens in Northern Ireland tends to be considered simply within its own context. As Paul Arthur explained, the fact that those involved were not "part of the metropolitan voice" has kept the NI movement out of the public eye ${ }^{94}$. Consequently, little or no effort has been made to frame the events of 1968 in Northern Ireland alongside those of other European countries. The role of those who spearheaded the " 68 movement in situating the memory of these events is important nationally and consequently on an international scale.

If we continue to take the French events as an example, it is obvious just how significant the role of those involved has been in shaping the image of 1968 that has since permeated the collective memory of $\mathrm{it}^{95}$. In fact, one of the most striking features of the history of May 68 in France is the fact that even before the crisis ended, a trend emerged that would see the verbosity that so characterised the revolt itself be transformed into an avalanche of participants' accounts ${ }^{96}$. As the periodic reassessments of the $10^{\text {th }}, 20^{\text {th }}, 30^{\text {th }}$ and now 40 th anniversary celebrations have demonstrated, the participants continue to be a significant vector in how the story of 1968 is told ${ }^{97}$. People such as Cohn-Bendit, Serge July or Henri Weber appear to revel in recalling their participation in these events in what Rioux describes as a "gigantesque mai pride ${ }^{98}$." This phenomenon has guaranteed a certain image of 1968 and propagated a perception of its impact on French society that has secured les événements a prominent place in the hearts and minds of the French. The same cannot be said for those that led the student movement of 1968 in Belfast. Such was the fallout of the 1968/69 period that any personal association with the PD created havoc with personal security and potential career prospects ${ }^{99}$. Therefore, unlike the French events which, almost immediately, were commemorated, celebrated and rendered mythical - largely by their very participants - the history of the PD has not been claimed with the same enthusiasm. This attitude is directly linked to the third and final reason that lies at the heart of why NI is so often absent from the long list of nations affected by the common, global 1968 revolt.

The events of 1968 are considered as a positive moment in the post WWII development of French society. This can be demonstrated in a number of ways. Firstly, a survey carried out in 2003/4 amongst French students demonstrated how almost three-quarters of young French people questioned believed 1968 to have been a positive moment for 
French society ${ }^{100}$. Furthermore, during the 2007 Presidential election campaign, the future President Nicolas Sarkozy attacked the impact of 1968 on French society and declared his desire to have its influence liquidated once and for all ${ }^{101}$. The reaction to this attack speaks volumes for the opposition to the notion that 1968 was anything other than a positive moment ${ }^{102}$. A 2008 poll ${ }^{103}$ confirmed the results as borne out by the 2003/4 survey as well as highlighting the widespread opposition ( $74 \%$ of those questioned) to the anti-'68 stance propagated by the President. It is clear then that the events of 1968 in France are considered as a positive moment, something to be celebrated and commemorated; a situation facilitated by the predominance of participants who are naturally keen to frame their actions positively, thus perpetuating the sanguine image.

In many respects it is this image of a positive moment that is dominant, not only in France but also across Europe and the world ${ }^{104}$. While much debate continues over the specific consequences of 1968 globally and on a national level, the overriding perception is one that holds it in a positive light as a watershed that helped move things forward. Once again however, and very significantly, this model is inapplicable to the case of Northern Ireland. The year 1968 marks the beginning of the "Troubles", i.e., over 30 years of sectarian violence that would so entrench religious divides that generations of peace building will be required before any genuine talk of normalcy can be taken seriously. With such a difference between the post- 68 years it can be of no surprise that it is considered in a different light. The enthusiasm with which the French events have been and continue to be fought over has, not surprisingly, been absent in the case of Northern Ireland where there has been a distinct lack of the "commemorative industry" so prevalent in France ${ }^{105}$. There were no noteworthy 10th, 20th or 30th anniversary celebrations. The context in Northern Ireland was so particular that inevitably so too were the consequences. The very dark, depressing and gloomy post-68 trajectory of Northern Ireland is in such stark contrast to the positive, modernising, liberating representation of the post-68 era on a European level (as typified by France) that it really does not come as any surprise that Northern Ireland has been left on the sidelines of the European collective memory of 1968.

\section{Conclusion}

Nevertheless, as with most things in Northern Ireland in recent times, change appears to be on the horizon. The success of the NI peace process has altered how the past is perceived. Last year "The 40th anniversary" of 1968 in Northern Ireland was the focus of a series of commemorative events ${ }^{106}$. There was even a clamour amongst the various political parties to appropriate the memory of 1968. It could be argued that those involved (principally the SDLP and Sinn Fein) hardly represent Northern Ireland's soixante-huitards and that their involvement was one based on the gleaning some political capital. Nevertheless, the shift has been significant. The fact that genuine participants now feel capable of coming forward and telling the story of Northern Ireland's 1968 provides the grounds for the history and memory of the events to be brought in line with the broader European perspective. With peace now very much a reality, 1968 can and will be considered in a more positive light, as an important turning point and therefore able to fit the mould of the European 1968. This has been reflected in the beginning of academic interest in this question with conference papers and texts looking at NI 68 from a global perspective ${ }^{107}$. 
contextual changes that will perhaps assist in ushering the Belfast 1968 into the stable of its European counterparts of the same year are only confirming a reality; that what happened in Northern Ireland in 1968 should be considered as part of the global revolt of that year. As was the case in France and around the world, Northern Ireland's 68 emerged from a sector of the population's youth no longer willing to accept the status quo. It shared the forms of action, language and systems of organisation with key participants clearly drawing inspiration from similar type revolts of that year. Finally, it was to have a considerable impact over the years that followed and as pointed out by the "1968 Commemoration Committee", "Such was the importance of these events, and what they led to, that it is appropriate and even necessary, 40 years later, to commemorate them." While the consequences were very different and in many respects explain why the memory has been framed otherwise and pushed in an alternative direction to that of the common narrative, what happened between October 1968 and February 1969 in Northern Ireland not only fits the ' 68 mould, in many respects it exemplifies it. As Eamonn McCann put it, "It is possible to argue that it was only in Northern Ireland that the events of 1968 left an indelible mark on events which continue to be played out 40 years later ${ }^{108 "}$.

\section{NOTES}

1. Several texts deal with the European/international dimension of 1968. See for example Ronald Fraser, 1968, a student generation in revolt, London, Chatto and Walls, 1988; GerdRainer Horn, The Spirit of '68, Rebellion in Western Europe and North America, 1956-76, Oxford, OUP, 2008.

2. For example, in France two documentaries were released in 2008 examining the international element of 1968: Michèle Dominici, "1968 un monde en révoltes", France Télévision, 2008; and Patrick Rotman, “'68”, France 2, 2008. Also, several conferences have been held to commemorate this 40th anniversary that have focussed on the global perspective of 1968. For example, Memories of 1968: International Perspectives, University of Leeds, 17-18 April 2008 and Les années 68: une contestation mondialisée, Colloque international, Nanterre, 19-20 March 2008.

3. As the above documentaries and conference programmes reveal, many countries were affected by the wave of protest including, Brazil, Mexico, the US, France, Italy, Germany, Czechoslovakia, Japan, China and many more.

4. S. O'Hagan, "Everyone to the barricades", The Observer, January 20, 2008.

5. One only has to consider the predominance of French iconography in how this year is portrayed. For example, photographs of the Parisian revolt together with reference to the famous utopian slogans are prominent in how the British media depict 1968. Cf. for example, Tariq Ali, "Where has all the rage gone? ", The Guardian, March 22, 2008; Robert Gildea, "1968 in 2008", History Today, May, 2008, p. 22-25; Gerard DeGroot, "Street-fighting men”, History Today, May, 2008, p. 26-33.

6. Robert Gildea, “1968 in 2008”, History Today, May, 2008, p. 22. 
7. Pierre Nora, Realms of Memory. Volume 1, Conflicts and divisions, New York, Columbia University Press, 1996, p. 609-37.

8. As is argued in Kristin Ross, Mai 68 et ses vies ultérieures (Paris, Complexe, 2002), and Isabelle Sommier, "Mai 68: sous les pavés d'une page officielle" (Sociétés Contemporaines, no. 20,1994, p. 63 ), a certain, narrow "official" history of mai 68 has come to dominate how the events are portrayed and thus perceived in France.

9. Cf. for example J. Harris, "I wasn't born in 1968 - but I yearn for its dizzying spirit”, The Guardian, March 21, 2008.

10. Chris Reynolds, "Understanding 1968: The Case of Brest", Modern and Contemporary France, Vol. 16, no. 2, 2008, p. 209-222; Chris Reynolds, "May 68: A Contested History", Sens Public, 26 October 2007, [http://www.sens-public.org/spip.php?article472], p. 18.

11. There exists an abundance of chronological accounts of the French events. For example, Christine Fauré, Mai 68 jour et nuit, Paris, Gallimard, 1998; Mavis Gallant, Chroniques de Mai 68, Paris, Rivages, 1998; Michel Gomez, Mai 68 au jour le jour, Paris, L'Esprit frappeur, 1998; Marie-Claire Lavabre, and Henry Rey, Les Mouvements de 1968, Firenze, Casterman, 1998; Annie Percheron, "Les événements de mai-juin 1968"; Revue politique et parlementaire, no. 102, 1999-2000; Antoine Prost, "Les grèves de mai-juin 1968", L'Histoire, n 110, April 1988, p. 34-47; Laurent Joffrin, Mai 68: Histoire des événements, Paris, Points, 2008.

12. Michael Seidman, The Imaginary Revolution. Parisian Students and Workers in 1968, New York, Berghan, 2004, p. 91-113.

13. Laurent Joffrin, Histoire des événements, p. 129-144.

14. Daniel Singer, Prelude to a Revolution, London, Jonathan Cape, 1970, p. 147-51.

15. Roger Martelli, Mai 68, Paris: Messidor, 1988, p. 102.

16. Hervé Hamon and Patrick Rotman, Génération. 1. Les Années de rêve, Paris, Seuil, 1987, p. 87; Chris Reynolds, “May 68: A Contested History”, p. 14-16.

17. Laurent Joffrin, Histoire des événements, p. 259.

18. Chris Reynolds, "May 68: A Contested History", p. 16-17.

19. Patrick Rotman, Mai 68 raconté à ceux qui ne l'ont pas vécu, Paris, Seuil, 2008, p. 115.

20. Chris Reynolds, "May 68: A Contested History”, p. 16.

21. Geneviève Dreyfus-Armand et al, Les Années 68: Le temps de la Contestation, Paris, Complexe, 2000.

22. Stefan Collini, "From Deference to Diversity," Common Reading/ Critics, Historians, Publics, Oxford, OUP, 2008, p. 270.

23. Ibid, p. 273.

24. Sabine Wichert, Northern Ireland since 1945, London, Longman, 1991, p. 109.

25. Jean-François Levy, “La People's Democracy”, Les Temps Modernes, no. 311, 1972, p. 2009-2047. See Bernadette Devlin's account of the personal impact participation in this march, The Price of my Soul, London, Pan, 1969, p. 99.

26. Simon Prince, Northern Ireland's 68. Civil Rights, Global Revolt and the Origins of the Troubles, Dublin, Irish Academic Press, 2007, p. 198.

27. Bernadette Devlin, The Price of my Soul, p. 204. There were initially six basic demands: One man, one vote; Fair (electoral) boundaries; Houses on Need; Jobs on Merit Free Speech; and the Repeal of the Special Powers Act. 
28. Ibid, p. 108. An example of such action was the 24 October (United Nations Day) occupation of the entrance hall to Stormont (the NI parliament). The PD carried out a sit down protest and refused to move until all MPs signed a statement declaring their support for the introduction of a human rights bill.

29. Ibid., p. 120.

30. Simon Prince, Northern Ireland's 68, p. 204.

31. Ibid., p.190-191; Bob Purdie, Politics in the Streets: the origins of the civil rights movement in Northern Ireland, Belfast, Blackstaff Press, 1990, p. 212-213.

32. Simon Prince, Northern Ireland's 68, p. 190.

33. Bernadette Devlin, The Price of my Soul, p. 115.

34. Paul Arthur, The People's Democracy 1968-73, Belfast, Blackstaff Press, 1974, p. 26.

35. Simon Prince, "The Global Revolt of 1968 and Northern Ireland", The Historical Journal, 49:3, 2006, p. 851-875 (p. 873).

36. Bowes Eagan and Vincent McCormack, Burntollet, London, LRS, 1969.

37. Bernadette Devlin, The Price of my Soul, p. 125-145; The Cameron report into Disturbances in Northern Ireland held "an enquiry into and report upon the course of events leading to and the immediate causes and nature of the violence and civil disturbance in Northern Ireland on and since 5th October 1968 and to assess the composition, conduct and aims of those bodies involved in the current agitation and any incidents arising out of it." (Cameron Report, Disturbances in Northern Ireland. Report of the Commission appointed by the Governor of Northern Ireland, September 1968, Chapter 9, paragraph 100).

38. Paul Arthur, Interview with author, 22 March, 2008.

39. Sabine Wichert, Northern Ireland since 1945, p. 110. It is interesting to note that Michael Farrell later referred to this election as a "Gaullist type strategy on the part of O'Neill" in Liam Baxter et al., "Discussion on the Strategy of People's Democracy", New Left Review I/55, 1969, p. 3-19 (p. 9).

40. Simon Prince, “The Global Revolt of 1968”, p. 874.

41. Martin Klimke and Joachim Scharloth, 1968 in Europe. A History of Protest and Activism, New York, Palgrave Macmillan, 2008.

42. Henri Weber, Faut-il liquider Mai 68? Essai sur les interprétations des 'événements', Paris, Seuil, 2008, p. 37-41.

43. Simon Prince, “The Global Revolt of 1968”, p. 867.

44. Eamon McCann, War and an Irish Town, London, Penguin, 1974, p. 43.

45. Sabine Wichert, Northern Ireland since 1945, p. 110.

46. Peter Gibbon, “The Dialectic of Religion and Class in Ulster", New Left Review, no. 55, 1969, p 20-41; p. 32-33.

47. Caroline Kennedy-Pipe, The Origins of the Present Troubles in Northern Ireland, London, Longman, 1997, p. 29-30.

48. Sabine Wichert, Northern Ireland since 1945, p. 87-92.

49. Paul Arthur, interview.

50. Maurice Agulhon et al, La France de 1940 à nos jours, Paris, Nathan/HER, 2001, p. 233.

51. Alain Touraine, Le Mouvement de mai ou le communisme utopique, Paris, Seuil, 1968, p. 84. 
52. Antoine Prost, "1968: mort et naissance de l'université française," in Vingtième Siècle, no. 23,1989 , p. 62 .

53. Paul Arthur, The People's Democracy, p. 8.

54. Peter Gibbon, “The Dialectic of Religion and Class in Ulster,” p. 33-34.

55. Ibid., p. 34.

56. Michael Farrell quoted in Baxter et al., "Discussion on the Strategy of the People's Democracy", p. 4.

57. Jean-François Levy, “La People’s Democracy”, p. 2011.

58. Paul Arthur, The People's Democracy, p. 20-21.

59. Bernadette Devlin, The Price of my Soul, p. 120.

60. Jean-Pierre Le Goff, Mai 68, l'héritage impossible, Paris, La Découverte, 1998, p. 129.

61. Bernadette Devlin, The Price of my Soul, p. 107.

62. McCann, War and an Irish town, p. 50; Paul Arthur, and Keith Jeffrey, Northern Ireland since 1968, Oxford, Basil Blackwell, 1988, p. 6.

63. Paul Arthur, Interview.

64. Simon Prince, Northern Ireland's 68, p. 148-149.

65. Niall O' Dochataigh, “Northern Ireland”, in Klimke and Scharloth, 1968 in Europe, p. 143-144.

66. Danielle Tartakowsky, Le Pouvoir est dans la rue, Paris, Aubier, 1998.

67. Simon Prince, “The Global Revolt of 1968”, p. 872-873.

68. Simon Prince, Northern Ireland's 68, p. 202.

69. Sommier, "Mai 68: Sous les pavés", p. 67.

70. Atelier Populaire, Posters from the revolution, London, Dobson, 1969; Ross, Mai 68 et ses vies ultérieures; Manus McGrogan, “Art on the Street", History Today, May 2008, p. 34-36; Philippe Artières, and Michelle Zancarini-Fournel, 68, Une Histoire Collective [1962-1981], Paris, La Découverte, p. 276-281. Examples of these posters can be found at [http:// achard.info/mai].

71. Examples of PD posters can be found on the following websites; [http:// www.museumoffreederry.org/index02.html] and [http://cain.ulst.ac.uk/index.html]. There is equally an impressive collection in the Linen Hall Street Library, Belfast.

72. Mulheron, Interview with author, 4 October, 2008.

73. Richard Johnson, The French Communist Party Versus the Students: Revolutionary Politics in May-June 1968, Yale, Yale University Press, 1972.

74. Jean-François Levy, “La People’s Democracy”, p. 2011.

75. Paul Arthur, Interview.

76. Hamon and Rotman, Génération. 1, p. 514-515.

77. Jean-François Sirinelli, Mai 68. L'événement Janus, Paris, Fayard, 2008, p. 263-267.

78. Laurent Joffrin, Histoire des événements, p. 350-353.

79. Bernadette Devlin, The Price of my Soul, p. 114-115.

80. Chris Reynolds, "May 68: A Contested History", p. 8-10.

81. Jacques Foccart, Le Général en Mai: Journal de l'Elysée - II. 1968-1969, Paris, Fayard/Jeune Afrique, 1998, p. 144-155. 
82. Simon Prince, Northern Ireland's 68, p. 191-192.

83. Michael Seidman, The Imaginary Revolution, p. 187-188.

84. Roger Martelli, Mai 68, p. 151-152.

85. Terence O'Neill quoted in Paul Arthur, The People's Democracy, p. 29.

86. Bernadette Devlin, The Price of my Soul, p. 107; Le Goff, Mai 68, l'héritage impossible, p. 125.

87. Paul Arthur, The People's Democracy, p. 20.

88. Term used by de Gaulle to describe the 1968 events during an interview with Michel Droit (7 July 1968).

89. Philippe Artières and Michelle Zancarini-Fournel. 68 Une Histoire Collective [1962-1981], Paris, La Découverte, p. 7.

90. Chris Reynolds, "May 68: A Contested History", p. 11-12.

91. Eamon McCann, Interview with author, 21 March, 2008.

92. Paul Arthur, Interview.

93. Roy Foster, Modern Ireland, 1600-1972, London, Penguin, 1988, p. 57.

94. Paul Arthur, Interview.

95. N. Weill, “Les années 1968 sans folklore ni pavés”, Le Monde, February 26, 2008.

96. Gilles Bousquet, “Où en est-on de mai 68? ”, Contemporary French Civilisation, no.1, 1992, p. 70.

97. One only has to consider the number of 40th anniversary texts authored by the now famous representatives of this generation such as Gérard Filoche, Mai 68, Histoire sans fin. Liquider mai 68? Même pas en rêve !, Paris, Jean-Claude Gawsewitch, 2007; Henri Weber, Fautil liquider Mai 68?; Daniel Cohn-Bendit, Forget 68, Paris, Editions de l'Aube, 2008; Rotman, Mai 68 raconté à ceux qui ne l'ont pas vécu; Alain Geismar, Mon Mai 68, Paris, Perrin, 2008. Notable also is the monopolisation of television coverage by a handful of actors who have come to dominate the image of these events.

98. Jean-Pierre Rioux, "L'événement-mémoire. Quarante ans de commémorations", Le Débat, no 149, March-April 2008, p. 4-19 (p. 15).

99. Arthur, Interview.

100. Chris Reynolds, "Current attitudes to the 'Events' of 1968: A Questionnaire", French Studies Bulletin, no. 98, 2006, p. 8-12.

101. D. Dhombres, “Une victime cachée de Mai-68”, Le Monde, May 2, 2008.

102. Sarkozy's controversial speech sparked a reaction that will almost certainly guarantee this decennial commemoration as the most productive thus far, E. Aeschimann, “Oui, Mai", Libération, February 1, 2008. For example, cf. Filoche, Mai 68, Histoire sans fin; Raphaël Glucksmann, and André Glucksmann, Mai 68 expliqué à Sarkozy, Paris, Denoël, 2008; Weber, Faut-il liquider Mai 68

103. M-F. Etchegoin and S. Courage, "Les Français votent 68”, Le Nouvel Observateur, March 27-April 2, 2008, p. 12-16. CSA poll conducted in conjunction with Le Nouvel Observateur.

104. Gérard DeGroot, “Street-Fighting Men”, p. 26.

105. Keith Reader, "Joyeux anniversaire! The May 68 industry", Modern and Contemporary France, vol. 8, no. 2, 2002, p. 249-252. 
106. L. Trainor, "Veterans of civil rights campaign launch 40th anniversary events," The Irish News, March 28, 2008. See [http://www.civilrights1968.com/index.html] for details.

107. For example, Manus McGrogan gave a paper which focused on NI in 1968 at the Les années 68 conference on Nanterre in March 2008 and Simon Prince's 2007 text is a vital step towards framing events in NI within the global context.

108. McCann, Interview.

\section{ABSTRACTS}

1968 is widely recognised as a year that saw great upheaval around the world. Whether in the USA, Czechoslovakia, Italy, Germany or Japan, governments were faced with a tide of revolts and insurrections of varying degrees and forms. It is clear that the French "événements" were, to a certain degree, inspired and influenced by what was happening elsewhere, perhaps explaining why so many similarities can be found on an international scale. Amongst those nations that experienced 1968 as a turning point in their development is Northern Ireland. This paper, through a comparison with the French events of 1968, will contend that Northern Ireland should be included in the list of countries that make up this international upheaval. Drawing on archival research, existing literature and in particular interviews with some of the major protagonists in the NI movement, it will investigate to what extent the international malaise and in particular the upheaval in France influenced events in Northern Ireland. Focussing on the student-based organisation The People's Democracy, it will be argued that the French May/June 1968 had some significant influence on an organisation whose protest over the 1968-69 period was to prove fundamental in the ensuing Northern Ireland Troubles.

1968 est généralement considérée comme une année qui a vu naître des insurrections importantes partout dans le monde. Que ce soit aux Etats-Unis, en Italie, en Allemagne ou au Japon, les gouvernements ont été confrontés à une vague de révoltes diverses et variées. Il est clair que les « évenéments » en France ont été inspirés et influencés par ce qui se passait ailleurs et ceci explique peut-être pourquoi on trouve tant de similarités à l'échelle internationale. Parmi les nations qui ont connu un tournant politique important en 1968, se trouve l'Irlande du Nord. Cet article, à travers une comparaison avec les événements français, avance l'idée que l'Irlande du Nord devrait faire partie de la liste des pays qui ont contribué à cette révolte globale. Utilisant des archives, la recherche existante et en particulier des entretiens avec un bon nombre d'acteurs principaux du mouvement irlandais, il examinera à quel point le malaise international, et plus particulièrement la révolte française a influencé ce qui s'est passé en Irlande du Nord. Se concentrant sur l'organisation étudiante The People's Democracy, cet article suggère que mai-juin 68 en France a été une influence fondamentale pour un mouvement qui, à travers ses actions pendant la période 1968-69, allait être très important lors des « Troubles » qui ont suivi. 
INDEX

Mots-clés: relations franco-irlandaises, Irlande du Nord - conflit, débat public, militantisme

Keywords: Franco-Irish relations, Northern Ireland - conflict, public debate, activism, trauma

\section{AUTHOR}

CHRIS REYNOLDS

Nottingham Trent University 